\title{
Investigation of Secondary Metabolites and Cytotoxicity of Jacquemontia pentantha (Jacq.)
}

\author{
Dina M Eskander',*, Ezzel -Din A El-Khrisy', Mary H Grace², Marian Nabil', Mahmoud I Nassar', Marwa M \\ Mounier $^{3}$
}

Dina M Eskander ${ }^{1, *}$, Ezzel -Din A El-Khrisy ${ }^{1}$, Mary H Grace ${ }^{2}$, Marian Nabil' ${ }^{1}$, Mahmoud I Nassar' ${ }^{1}$, Marwa M Mounier ${ }^{3}$

'Chemistry of Natural Compounds Department, National Research Centre, Dokki, 12622 Cairo, EGYPT.

2Plants for Human Health Institute, Food Bioprocessing and Nutrition Sciences Department, North Carolina State University, North Carolina Research Campus, NC, USA.

${ }^{3}$ Department of Pharmacognosy, Drug Bioassay-Cell Culture Laboratory, National Research Centre, Dokki, 12622 Cairo, EGYPT.

\section{Correspondence}

Dina Mahfouz Eskander

Department of Chemistry of Natural Compounds, National Research Centre,

Dokki, 12622 Cairo, EGYPT.

E-mail: dina226@hotmail.com

History

- Submission Date: 16-03-2019.

- Review completed: 18-04-2019;

- Accepted Date: 24-04-2019

\section{DOI : 10.5530/pj.2019.11.114}

Article Available online http://www.phcogj.com/v11/i4

Copyright

(C) 2019 Phcogj.Com. This is an openaccess article distributed under the terms of the Creative Commons Attribution 4.0 International license.

\begin{abstract}
Introduction: The aim of this study is to isolate and identify sterols and terpenes from the chloroform/methanol extract (3:1) of aerial parts of Jacquemontia pentantha (Jacq.) and evaluation of cytotoxic activity of crude extract and phytol for the first time from this plant. Methods: Different chromatographic techniques for the aerial parts of Jacquemontia pentantha extract were used resulting in isolation of eight compounds. Their structures were elucidated by spectroscopic methods including ${ }^{1} \mathrm{HNMR},{ }^{13} \mathrm{CNMR}, \mathrm{EI} / \mathrm{MS}$ spectrometry and by comparing their data with those reported in the literature. The cytotoxicity was evaluated using MTT assay. The mode of action of the extract was predicted by using Enzyme-linked Immunosorbent Assay Kit for Tubulin beta (TUBb). Results: Eight compounds for the first time from this plant were identified as Palmitic acid (1), Phytol (major) (2), Stigmast-4-en3-one (3), mixture of $\alpha$-amyrin (4) and $\beta$-amyrin (5), 1,6,10,14,18,22-Tetracosahexaen-3ol,2,6,10,15,19,23-hexamethyl (all-E) (6) and mixture of $\alpha$-amyrin acetate (7) and $\beta$-amyrin acetate (8). The extract showed potent cytotoxic activity on MCF-7 breast carcinoma cell line as well as HCT-116 colon carcinoma cell line at different concentrations $(100-6.25 \mathrm{ug} / \mathrm{ml})$ with $\mathrm{IC}_{50}(21.8 \pm 0.9)$ and $(40.9 \pm 1.3)$ respectively. Phytol showed potent cytotoxic activity on MCF-7 cell line at different concentrations $(100-12.5 \mathrm{ug} / \mathrm{ml})$ with $\mathrm{IC}_{50}(60 \pm 2.4)$, while it had no cytotoxic effect on HCT-116 cell line. The extract showed significant TUBb polymerization inhibition activity. Conclusion: The extract of aerial parts of Jacquemontia pentantha (Jacq.) and also phytol compound has cytotoxic activity due to the presence of phytochemicals such as sterols and terpenes.
\end{abstract}

Key words: Cytotoxic activity, enzyme-linked immunosorbent assay, Jacquemontia pentantha, MTT assay, sterols, terpenes.

\section{INTRODUCTION}

Jacquemontia pentantha (Jacq.) belongs to family Convolvulaceae, which includes 55 genera and 1650 species, distributed in both tropical and temperate regions of the world. ${ }^{1}$ Jacquemontia pentantha is an attractive ornamental plant, spreading in tropical and subtropical countries including the West African Region. ${ }^{2}$ Chemically, many species of this family include phytoconstituents as; alkaloids, ${ }^{3}$ flavonoids, as well as terpenoids and coumarins. ${ }^{4}$ Bioactivities, reported in these species were antioxidant, ${ }^{5}$ antimicrobial, ${ }^{6}$ antiinflammatory, ${ }^{7}$ antidiabetic, ${ }^{8}$ and anticancer activity. ${ }^{9}$ Convolvulaceae importance as a source of food and drugs has been reported. ${ }^{1}$ Worldwide cancer is a life- threatening disease affecting human populations globally. There is a constant need for discovering new candidate to treat and prevent cancer. Scientific research interest is directed towards plant kingdom due to their wide diversity of naturally-occurring secondary metabolites with less toxic side effects compared to current chemotherapeutic drugs used in pharmaceutical market. Continuing our work on this species, ${ }^{2,10}$ this study aims to characterize the chemical constituents (sterols and terpenes) of Jacquemontia pentantha aerial parts, cultivated in Egypt, for the first time from this plant, to support the possibility of its uses as a natural resource in therapeutics. Also to demonstrate the cytotoxic activity of the extract and phytol, which hasn't been investigated before for this plant.

\section{MATERIALS AND METHODS}

\section{Collection of plant material}

The aerial parts of Jacquemontia pentantha (Jacq.) (Family Convolvulaceae) were collected from ElOrman garden, Giza, Egypt, in July 2017. The plant was identified by Mm. Tressa Labib, Taxonomist, ElOrman garden, Giza, Egypt. The plant samples were air-dried, powdered and kept for phytochemical and bioactivity studies.

\section{Instrumentation}

NMR spectra were recorded on a Jeol Ex-600 $\mathrm{MHz}$ NMR spectrometer, using TMS as internal standard. UV spectrometer (Schimadzu UV240) and mass spectra EI-MS (Varian MAT at $70 \mathrm{ev}$ ) were used. Column chromatography (CC) was carried out on silica gel F254 (Merck) in glass blades. TLC was performed with silica gel 60 GF254 plates (Merck, Darmstadt, Germany), 
then the plates were visualized using UV light and by spraying with vanillin in $\mathrm{H}_{2} \mathrm{SO}_{4}$.

\section{Isolation and extraction of the compounds}

The air-dried powdered aerial parts of Jacquemontia pentantha $(1 \mathrm{~kg})$ was extracted with chloroform-methanol (3:1) till exhaustion. The extract was evaporated under reduced pressure to yield $100 \mathrm{~g}$ crude extract. A portion of this extract $(70 \mathrm{~g})$ was subjected to silica gel $(60-$ 120 mesh, Merck) column chromatography, eluted with petroleum ether, followed by methylene chloride step-gradient, starting with $100 \%$ petroleum ether. Then, the column was eluted with gradient of methylene chloride/methanol (100:0, 9:1, 7:3, 1:1 and 0:100). The elutes were monitored using TLC, and were viewed under UV light (254 and $365 \mathrm{~nm}$ ) and by spraying with $1 \%$ vanillin/ $5 \% \mathrm{H}_{2} \mathrm{SO}_{4} / \mathrm{EtOH}$ reagent, followed by heating at $100^{\circ} \mathrm{C}$. The fractions obtained were collected and combined on the basis of TLC profiles, to give five major fractions from which 8 compounds were obtained. Fraction 1: It was subjected to silica gel column, eluted by $20 \%$ methylene chloride in petroleum ether and was purified by TLC on silica gel "G" plate using petroleum ether: ethyl acetate (9:1) as developing system, giving compound $\mathbf{1}$ (3.7 mg). Fraction 2: It was subjected to silica gel column, eluted by $30 \%$ methylene chloride in petroleum ether and was purified by TLC on silica gel "G" plate using petroleum ether: ethyl acetate $(9: 1)$ as developing system, giving major compound 2 (65.4 mg). Fraction 3: It was subjected to silica gel column, eluted by $30 \%$ methylene chloride in petroleum ether and was purified by TLC on silica gel " $G$ " plate using petroleum ether: ethyl acetate $(9: 1)$ as developing system, giving compound $3(5.3 \mathrm{mg})$. Fraction 4: It was subjected to silica gel column, eluted by $30 \%$ methylene chloride in petroleum ether and was purified by TLC on silica gel "G" plate using petroleum ether : ethyl acetate $(8: 2)$ as developing system, giving mixture of compound $\mathbf{4 , 5}$ ( $13.6 \mathrm{mg}$ ), then it was eluted by $40 \%$ methylene chloride in petroleum ether and was purified by TLC on silica gel "G" plate using petroleum ether : ethyl acetate $(8: 2)$ as developing system, giving compound $6(5.8 \mathrm{mg})$. Fraction 5: It was subjected to silica gel column, eluted by $50 \%$ methylene chloride in petroleum ether and was purified by TLC on silica gel "G" plate using petroleum ether: ethyl acetate (8:2) as developing system, giving mixture of compound 7 and compound $8(10.3 \mathrm{mg})$. The isolated compounds were identified on the basis of UV, Mass spectrum, ${ }^{1} \mathrm{HNMR}$ and ${ }^{13} \mathrm{CNMR}$ data and compared with literature.

\section{Cell lines}

Human breast carcinoma (MCF-7 cell line), colon carcinoma (HCT116 cell line) were obtained from Karolinska Center, Department of Oncology and Pathology, Karolinska Institute and Hospital, Stockholm, Sweden.

\section{Cell culture}

The procedure was done in a sterile area using a laminar air flow cabinet biosafety class II level. Culture was maintained in RPMI 1640 medium with $1 \%$ antibiotic-antimycotic mixture $(10.000 \mathrm{U} / \mathrm{ml}$ potassium penicillin, $10.000 \mu \mathrm{g} / \mathrm{ml}$ streptomycin sulfate and $25 \mu \mathrm{g} /$ $\mathrm{ml}$ amphotericin B), 1\% L-glutamine, and supplemented with $10 \%$ heat inactivated fetal bovine serum. Culturing and subculturing were carried out according to. ${ }^{11}$ Doxorubicin was used as a positive control. A negative control composed of DMSO was also used.

\section{Cell viability assay}

This was done according to,${ }^{12}$ as described by Mosmann T. ${ }^{13}$ Following culturing for 10 days, the cells were seeded at concentration of $10 \times 10^{3}$ cells per well in case of MCF-7 and $20 \times 103$ cells/well in a fresh complete growth medium in case of HCT-116 cell lines, using 96-well microtiter plastic plates at $37^{\circ} \mathrm{C}$ for 24 hours under $5 \% \mathrm{CO} 2$, in a water jacketed carbon dioxide incubator. Fresh medium (without serum) was added, and cells were incubated either alone (negative control) or with samples, to give a final concentration of $100 \mu \mathrm{g} / \mathrm{ml}$. After 48 hours incubation, the medium was aspirated and then $40 \mu \mathrm{l}$ MTT salt $(2.5 \mathrm{mg} /$ $\mathrm{ml}$ ) were added. To stop the reaction and dissolve the formed crystals, $200 \mu 10 \%$ sodium dodecyl sulphate (SDS) was added. The absorbance was measured using a microplate multi-well reader at $595 \mathrm{~nm}$ and a reference wavelength of $690 \mathrm{~nm}$.

\section{Determination of $\mathrm{IC}_{50}$ values}

$\mathrm{IC}_{50}$ values were calculated using probit analysis and utilizing the SPSS computer program (SPSS for windows, statistical analysis software package /version 9/ 1989 SPSS Inc., Chicago, USA).

All experimental data stated in this work were expressed as the average \pm standard deviation (SD) for $\mathrm{n}=3$ and were analyzed using standard analysis of Student's t-test. The level of significance (p-value) is set at < 0.05 .

\section{Enzyme-linked immunosorbent assay kit for tubulin beta (TUBb)}

MCF-7 cells were cultured using DMEM (supplemented with $10 \%$ FBS and with $1 \%$ antibiotic-antimycotic mixture $(10.000 \mathrm{U} / \mathrm{ml}$ potassium penicillin, $10.000 \mu \mathrm{g} / \mathrm{ml}$ streptomycin sulfate and $25 \mu \mathrm{g} / \mathrm{ml}$ amphotericin B). Plate cells (cells density $1.2-1.8 \times 10.000$ cells/well) were kept in a volume of $100 \mu \mathrm{l}$ complete growth medium $+100 \mathrm{ul}$ of the tested compound per well in a 96 well plate for 18-24 hours, before the enzyme assay for Tubulin. The microtiter plate provided in this kit had been pre-coated with an antibody specific to TUBb. Standards or samples were then added to the appropriate microtiter plate wells with a biotin-conjugated antibody specific to TUBb. Next, Avidin conjugated to Horseradish Peroxidase (HRP) was added to each microplate well and were incubated. After TMB substrate solution was added, only those wells that contain TUBb, biotin-conjugated antibody and enzymeconjugated Avidin would exhibit a change in color. The enzymesubstrate reaction was terminated by the addition of sulphuric acid solution and the color change was measured spectrophotometrically at a wavelength of $450 \mathrm{~nm} \pm 10 \mathrm{~nm}$. The concentration of TUBb in the samples was then determined by comparing the O.D. of the samples to the standard curve. ${ }^{14}$

\section{RESULTS}

Eight compounds from the extract chloroform-methanol (3:1) of aerial parts of Jacquemontia pentantha were identified for the first time as: Palmitic acid (1), Phytol (major) (2), Stigmast-4-en-3-one (3), mixture of $\alpha$-amyrin (4) and $\beta$-amyrin (5), 1,6,10,14,18,22-Tetracosahexaen3 -ol,2,6,10,15,19,23-hexamethyl (all-E) (6) and mixture of $\alpha$ - amyrin acetate (7) and $\beta$-amyrin acetate (8). The isolated compounds were identified on the basis of UV, Mass spectrum, ${ }^{1} \mathrm{HNMR}$ and ${ }^{13} \mathrm{CNMR}$ data and compared with literature. The following compounds were identified with their physical and spectroscopic data:

Palmitic acid (1): Colorless powder, $[\mathrm{M}]+m / z 256$. Molecular formula $\mathrm{C}_{16} \mathrm{H}_{32} \mathrm{O}_{2}$. UV: $\lambda \max 220 \mathrm{~nm} .{ }^{1} \mathrm{HNMR}\left[\mathrm{CDCl}_{3}: 600 \mathrm{MHz}\right] \delta[\mathrm{ppm}]: 0.87$ $\left[\mathrm{t}, J=6.5 \mathrm{~Hz} . \mathrm{H}_{3}: 16\right], 1.22-1.28\left(24 \mathrm{H}, 2 \mathrm{H}_{4} \rightarrow 2 \mathrm{H}_{15}\right), 1.62(2 \mathrm{H}, J=7.5 \mathrm{~Hz}$, $2 \mathrm{H}: 3), 2.21[\mathrm{t}, J=6.7 \mathrm{~Hz} .2 \mathrm{H}: 2] .{ }^{13} \mathrm{CNMR}\left[\mathrm{CDCl}_{3,} 150 \mathrm{MHz}\right] \delta[\mathrm{ppm}]:$ 24.4, 28.7, 31.8 [C $(1,2,3)]$ respectively, 28.6 [m, C:4 to C:13], 25.86, $34.2,179.2[\mathrm{C}(14,15,16)]$ respectively. Compound was confirmed to be palmitic acid by comparing its spectral data with the literature. ${ }^{15,16}$

Phytol (2): Yellow oil, $[\mathrm{M}]+m / z$ 296, Molecular formula $\mathrm{C}_{20} \mathrm{H}_{40} \mathrm{O}$. ${ }^{1} \mathrm{HNMR}\left[\mathrm{CDCl}_{3}: 600 \mathrm{MHz}\right.$ ]: $\delta 1.67[\mathrm{~s}, \mathrm{OH}], \delta 4.13$ [d, H:1], $\delta 5.38$ [t, H:2], $\delta 1.96$ [t, H:4], $\delta 1.42-\delta 1.33$ [m,H: 7, H:11], $\delta 1.31-\delta 1.02$ [m, H:6, 8, 9,10,12,13], $\delta 1.64$ [s, H:20]. ${ }^{13} \mathrm{CNMR}\left[\mathrm{CDCl}_{3}, 150 \mathrm{MHz}\right.$ : 
$\delta 59.47,123.07,140.11,40.02,25.1[\mathrm{C}(1,2,3,4,5)]$ respectively, 35.11, $31.12,37.37,24.88,37.41[\mathrm{C}(6,7,8,9,10)]$ respectively, 33.12, 37.25, $25.21,39.78,27.88$ [C $(11,12,13,14,15)]$ respectively, 22.62, 22.68, $19.65,19.73,16.15[\mathrm{C}(16,17,18,19,20)]$ respectively. Comparison of the spectral data with literature confirmed compound as phytol. ${ }^{17,18}$

Stigmast-4-en-3-one (3): Colorless oily matter; [M+] $\mathrm{m} / \mathrm{z}_{4} 412$, Molecular formula $\mathrm{C}_{29} \mathrm{H}_{48} \mathrm{O}$.

${ }^{1} \mathrm{HNMR}\left[\mathrm{CDCl}_{3}: 600 \mathrm{MHz}\right.$ ]: $\delta 5.71[\mathrm{~d}, \mathrm{~J}=2.2 \mathrm{~Hz}, \mathrm{H}: 4], \delta 1.17$ [s, 3H, 19:CH3], $\delta 0.91$ [d, 3H, J=6.4 Hz, 29:CH3], $\delta 0.81 \sim \delta 0.82[9 \mathrm{H}, \mathrm{m}$, $\left.3 \mathrm{CH}_{3}: 21,26,27\right], \delta 0.73\left[3 \mathrm{H}, \mathrm{S}, \mathrm{CH}_{3}: 18\right] .{ }^{13} \mathrm{CNMR}\left[\mathrm{CDCl}_{3}: 150 \mathrm{MHz}\right]$ spectrum: $\delta 34.7,32.7,198.4,122.6,170.4[\mathrm{C}(1,2,3,4,5)]$ respectively, $31.8,31.1,34.5,52.6,37.4[\mathrm{C}(6,7,8,9,10)]$ respectively, 22.1, 38.4, 41.2, 54.7, $25.1[\mathrm{C}(11,12,13,14,15)]$ respectively, 27.0, 54.7, 10.7, 18.1, 35.1 [C $(16,17,18,19,20)]$ respectively, 16.1, 32.6, 23.0, 43.7, 26.1 [C (21, $22,23,24,25)]$ respectively, 18.5, 17.4, 22.9, 10.7 [C (26, 27, 28, 29)] respectively. It was confirmed as stigmast-4-en-3-one by comparison the spectral data of the compound with the literature. ${ }^{19,20}$

$\boldsymbol{\alpha}$-Amyrin (4): Colorless amorphous solid. [M+] $m / z$ 426, UV: 274, 257, $243 \mathrm{~nm}$. Molecular formula $\mathrm{C}_{30} \mathrm{H}_{50} \mathrm{O} .{ }^{1} \mathrm{HNMR}$ [CDCl $: 600 \mathrm{MHz}$ ]: $\delta$ $5.10[\mathrm{H}: 12, \mathrm{t}, J=3.5 \mathrm{~Hz}], 3.19[\mathrm{H}: 3, \mathrm{dd}, J=5.0,11.0 \mathrm{~Hz}], 1.01,0.94,0.93$, $0.89,0.72,0.71\left[\mathrm{CH}_{3}(27,28,23,26,24,25), \mathrm{s}\right], 0.85[\mathrm{CH} 3: 29, \mathrm{~d}, J=6.0$ $\mathrm{Hz}$ ], 0.74 [CH3: 30, d, $J=7.0 \mathrm{~Hz}] .{ }^{13} \mathrm{C}$ NMR [150 MHz: $\left.\mathrm{CDCl}_{3}\right]: \delta 124.4$ [HC=, C:12], 139.5 [C:13] , 38.5, 28.6, 79.1, 38.7, 55.2 [C $(1,2,3,4,5)]$ respectively, $18.3,32.6,40.0,47.6,36.8[\mathrm{C}(6,7,8,9,10)]$ respectively, $23.4,42.1,27.8,26.5,33.5$, [C $(11,14,15,16,17)]$ respectively, 59.2, 39.5, $39.5,31.2,41.5[\mathrm{C}(18,19,20,21,22)]$ respectively, 28.0, 15.6, 15.6, 16.9, $23.1[\mathrm{C}(23,24,25,26,27)]$ respectively, $28.7,17.4,21.3$ [C $(28,29,30)]$ respectively. The data for this compound was assigned by comparison with the corresponding in the published spectrum of $\alpha$-Amyrin. ${ }^{21-23}$

$\beta$-Amyrin (5): Colorless amorphous solid. $[\mathrm{M}+] m / z 426, \mathrm{UV}: \lambda \max 245$ nm. Molecular formula $\mathrm{C}_{30} \mathrm{H}_{50} \mathrm{O} .{ }^{1} \mathrm{H}$ NMR: $\left[\mathrm{CDCl}_{3}, 600 \mathrm{MHz}\right]: \delta 5.15$ $[\mathrm{H}: 12, \mathrm{t}, J=3.2 \mathrm{~Hz}], 3.21[\mathrm{H}: 3, \mathrm{dd}, \mathrm{J}=11.0,5.2 \mathrm{~Hz}], 0.77-1.11[\mathrm{~s}, \mathrm{CH} 3]$, $1.84[\mathrm{H}: 22, \mathrm{~m}], 1.88[\mathrm{H}: 15, \mathrm{~m}] .{ }^{13} \mathrm{C} \mathrm{NMR}\left[150 \mathrm{MHz}: \mathrm{CDCl}_{3}\right]: \delta 121.7$ [HC=, C:12], 145.2 [C:13], 38.6, 27.2, 79.0, 38.5, 55.1 [C (1,2,3,4,5)] respectively, 18.4, 32.9, 39.8, 47.6, 36.9 [C $(6,7,8,9,10)]$ respectively, 23.5, 41.7, 27.3, 26.2, $32.9[\mathrm{C}(11,14,15,16,17)]$ respectively, 47.2, 46.8, $31.1,34.8,37.1[\mathrm{C}(18,19,20,21,22)]$ respectively, 28.1, 15.4, 15.6, 16.8, 25.9 [C $(23,24,25,26,27)]$ respectively, $28.1,33.3,23.7$ [C(28,29,30)] respectively. The spectral data was compared with those previously reported. ${ }^{21}$

1,6,10,14,18,22-Tetracosahexaen-3-ol,2,6,10,15,19,23-hexamethyl-, (all-E) (6): Colorless oil. [M] $m / z 426$, molecular formula $\mathrm{C}_{30} \mathrm{H}_{50} \mathrm{O}$. ${ }^{1} \mathrm{HNMR}$ [600 MHz, $\left.\mathrm{CDCl}_{3}\right]: \delta 5.42[1 \mathrm{H}(3), \mathrm{d}, \mathrm{J}=6.9 \mathrm{~Hz}], 5.12[5 \mathrm{H}(7$, $14,11,18,22)$, t, $J=6.9 \mathrm{~Hz}], \delta 5.01[2 \mathrm{H}(1), \mathrm{d}, J=6.9 \mathrm{~Hz}], 1.91-2.05$ $[10 \mathrm{H}, \mathrm{m}], 1.97[10 \mathrm{H}(4,5,8,9,12,13,16,17,20,21) \mathrm{m}], 1.67[3 \mathrm{H}$ $(24-\mathrm{Me}), \mathrm{s}], 1.61$ [18H (C ( 2 - Me, 6 - Me, $10-\mathrm{Me}, 15-\mathrm{Me}, 19-\mathrm{Me}$, 23-Me), s]. ${ }^{13} \mathrm{CNMR}$ [150 MHz:CDCl$]$ ] 116.10 [C:1], 148.2 [C:2], 131.2 [C:23], 25.70 [C:24], 134.5 [C - C $(7,11,15,19)]$ respectively, 124.4, $124.3,124.3,124.2,124.2[\mathrm{CH}-\mathrm{C}(6,10,14,18,22)]$ respectively, 39.74 , $39.73,39.71,37.47,37.01\left[\mathrm{CH}_{2}-\mathrm{C}(5,9,13,17,21)\right]$ respectively, 26.79 , $26.77,26.71,26.68,26.62\left[\mathrm{CH}_{2}-\mathrm{C}(4,8,12,16,20)\right]$ respectively, 17.67, $16.45,16.03,16.01,15.95,15.89\left[\mathrm{CH}_{3}-\mathrm{C}(25,26,27,28,29,30)\right]$ respectively. Compound was confirmed by comparing its spectral data with squalene and its derivatives literature. ${ }^{24,25}$ The spectroscopic data of this compound is reported here for the first time as it was identified previously only by GC/MS of plant Sauropus bacciformis Blume. ${ }^{24-26}$

a-amyrin acetate (7): White powder. $[\mathrm{M}]+m / z 468$. Molecular formula $\mathrm{C}_{32} \mathrm{H}_{52} \mathrm{O}_{2} \cdot{ }^{1} \mathrm{HNMR}\left[\mathrm{CDCl}_{3}, 600 \mathrm{MHz}\right] \delta[\mathrm{ppm}]: 5.1[\mathrm{dt}, \mathrm{J}=8 \mathrm{~Hz}$ and $\mathrm{J}=$ $4 \mathrm{~Hz}, \mathrm{H}: 12$ ], 4.4 [m, H:3], 0.80 [s], 0.83 [s], 0.88 [s], 0.92 [s], 0.98 [s], 1.0 [s], $2.05[\mathrm{~s}] .{ }^{13} \mathrm{CNMR}\left[\mathrm{CDCl}_{3}, 150 \mathrm{MHz}\right] \delta[\mathrm{ppm}]: 124.3$ [C:12], 140.1 [C:13], 37.80, 23.75, 80.59, 38.14, 55.50 [C $(1,2,3,4,5)]$ respectively, $18.59,32.69,39.6,48.47,36.4$, [C $(6,7,8,9,10)]$ respectively, 22.07, 42.10,
26.68, 27.42, 33.7 [C $(11,14,15,16,17)]$ respectively, 59.30, 39.5, 31.1, $41.5,14.53$ [C $(18,19,21,22,23)]$ respectively, $28.19,16.13,16.14$, $19.02,18.25,18.57$ [C $(24,25,26,27,28,30)]$ respectively, 172.02 [C:1'], 21.42 [CH3]. The spectral data was compared with those previously reported..$^{27,28}$

B-amyrin acetate (8): White powder. $[\mathrm{M}]+m / z 468$. Molecular formula $\mathrm{C}_{32} \mathrm{H}_{52} \mathrm{O}_{2} .{ }^{1} \mathrm{HNMR}\left[600 \mathrm{MHz}, \mathrm{CDCl}_{3}\right.$ ] $\delta$ [ppm]: 5.13 [t, H:12], 4.4 [m, $\mathrm{H}: 3$ ], 1.13 [ s, $\mathrm{CH}_{3}: 27$ ] 0.962 [s, CH3:26], 0.96 [s, $\left.\mathrm{CH}_{3}: 25\right], 0.87$ [s, $\mathrm{CH}_{3}: 29$ and $\left.\mathrm{CH} 3: 30\right], 0.86$ [s, $\left.\mathrm{CH}_{3}: 24\right], 0.83$ [s, $\left.\mathrm{CH}_{3}: 23\right], 0.82$ [s, $\left.\mathrm{CH}_{3}: 28\right]$, $2.2\left[\mathrm{H}: 2\right.$ '] ${ }^{13} \mathrm{CNMR}$ [CDCl, $\left.150 \mathrm{MHz}\right] \delta$ [ppm]: 121.65 [C:12], 145.21 [C:13], 38.10, 22.27, 80.28, 37.10, 55.20 [C (1,2,3,4,5)] respectively, $18.71,32.50,39.70,47.50,36.91$ [C $(6,7,8,9,10)]$ respectively, 23.50, $41.70,26.20,26.21,32.5$ [C $(11,14,15,16,17)]$ respectively], 47.10, $46.79,31.1,34.6,37.1$ [C $(18,19,20,21,22)]$ respectively, 16.78, 28.40, $15.51,25.92,23.40,33.20$ [C $(23,24,25,27,28,29)]$ respectively, 171.08 (C:1'), 34.75 (C:2'). All these assignments were consistent with the data obtained from literature for beta-amyrin acetate. ${ }^{27}$

These compounds were isolated here from Jacquemontia pentantha for the first time. Spectral data of the isolated compounds were in accordance with previously reported spectral data. Phytol is reported here as a major compound.

\section{Cell viability assay (MTT assay)}

The results revealed that the crude extract showed potent cytotoxic activity on both breast and colon human cell lines at different range of concentration (100-6.25 ug/ml) with $\mathrm{IC}_{50}(21.8 \pm 0.9)$ and $(40.9 \pm 1.3)$ respectively. The antiproliferative potentency represented by $\mathrm{IC}_{50}$ value, the $\mathrm{IC}_{50}$ value is reverse proportional with the activity (i.e.,: the less $\mathrm{IC}_{50}$ value the more potent antiproliferative activity). The crude extract showed more potency than the drug reference doxorubicin on breast tumor cell line as shown in (Figure 1).

\section{Enzyme-linked immunosorbent assay kit for tubulin beta (TUBb)}

To elucidate the possible mode of action of antiproliferative effect of crude extract of Jacquemontia pentantha on breast tumor cell line as shown in (Figure 1), Enzyme-linked Immunosorbent Assay Kit for Tubulin beta (TUBb) assay was done. The percentage inhibition of tubulin (TUBb) polymerization against breast cancer cell lines was

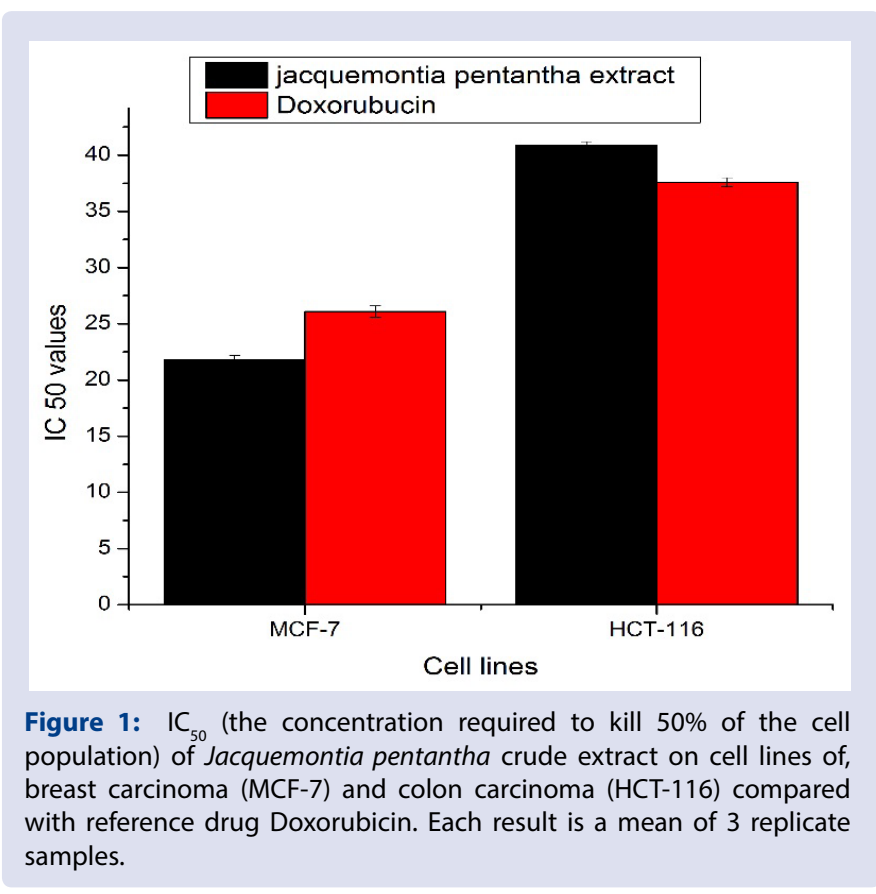


measured using colchicine as a reference drug. The tested extract of Jacquemontia pentantha showed significant $\mathrm{TUBb}$ polymerization inhibition activity with statistically significant $(\mathrm{p}<0.05)$. Its activity was higher than colchicine as TUBb polymerization inhibitors (Figures 2 and 3, Table 1) in accordance with the in vitro anti-cancer activity of this extract against MCF-7 cell line. In conclusion: Jacquemontia pentantha extract has antiproliferative effect on two tumor cell line namely (MCF-7 and HCT-116). The anti- proliferative effect on breast cell line is through affecting microtubule-polymer mass resulting in cell death.

\section{Cytotoxic effect of phytol}

The cytotoxic activity of phytol was screened on both colon and breast cell line at concentration $(100-12.5 \mathrm{ug} / \mathrm{ml})$. The results revealed that the compound had no cytotoxic effect on colon HCT-116 cell line, on the other hand it possessed potent cytotoxic activity on MCF-7 breast cell line, with $\mathrm{IC}_{50}(60 \pm 2.4)$ as seen in (Figure 4). According to the above

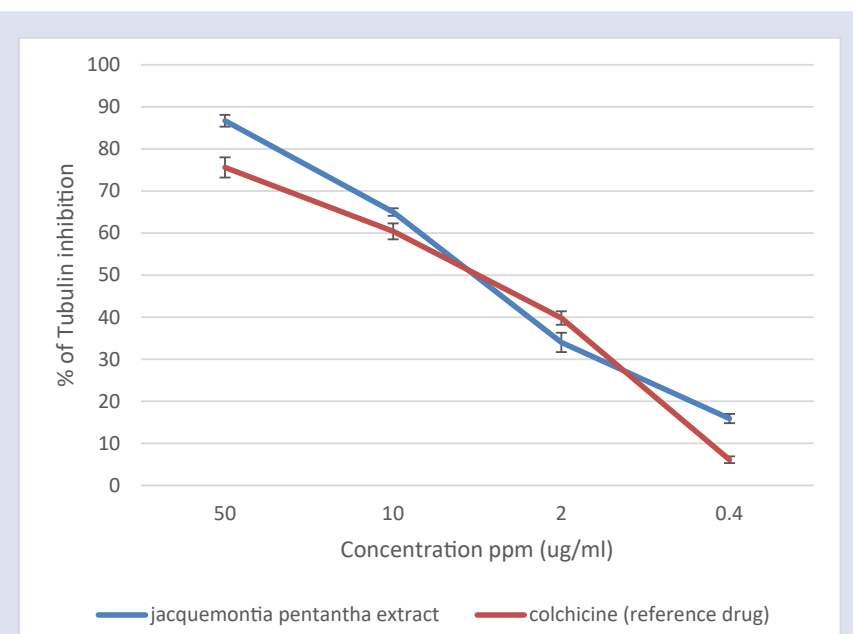

Figure 2: Tubulin polymerization inhibition of Jacquemontia pentantha crude extract on MCF-7 at different concentration compared with colchicine reference drug. Each result is a mean of 3 replicate samples.

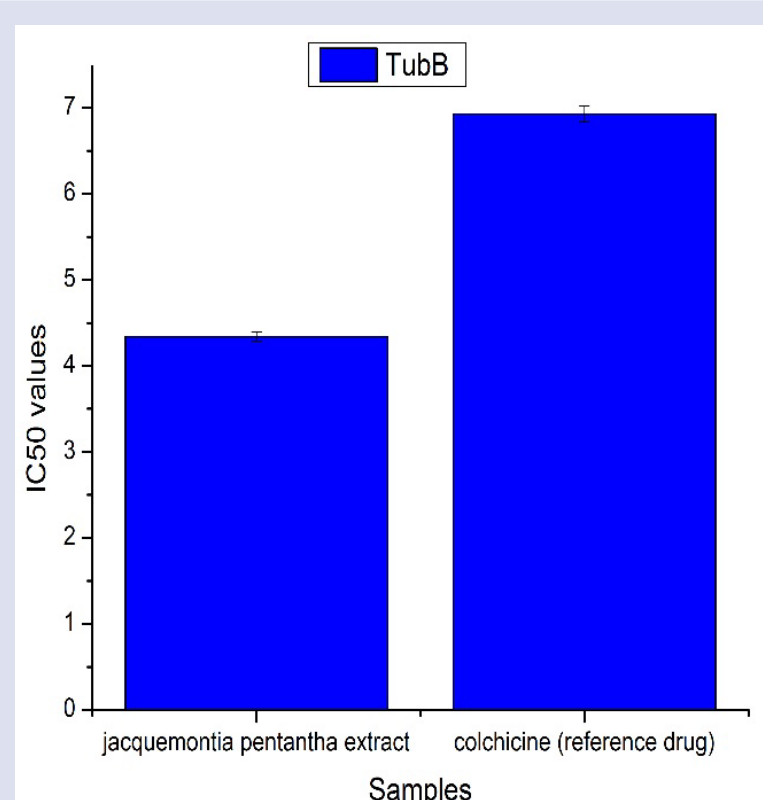

Figure 3: $\mathrm{IC}_{50}$ of Jacquemontia pentantha extract on TubB inhibition using (MCF-7), $p<0.05$. Each result is a mean of 3 replicate samples.
Table 1: Tubulin polymerization inhibition of crude extract on MCF-7. $p$ $<0.05$.

\begin{tabular}{cccc}
\hline \multicolumn{3}{c}{ MCF-7 } \\
\hline $\begin{array}{c}\text { IC50 values } \\
\text { ug/ml }\end{array}$ & Tubulin\% inhibition & conc. ug/ml & Cpd. code. \\
\hline 4.34 & 86.73123 & 50 & Crude Extract \\
& 65.02825 & 10 & \\
& 34.03551 & 2 & \\
& 15.89992 & 0.4 & \\
6.93 & 75.64169 & 50 & REF (colchicine) \\
& 60.43066 & 10 & \\
& 39.78467 & 2 & \\
& 6.115418 & 0.4 & \\
\hline
\end{tabular}

MCF-7: Human breast carcinoma; $I C_{5}:$ The concentration required to kill $50 \%$ of the cell population; Conc: Concentration; Cpd: Compound; REF: Reference.

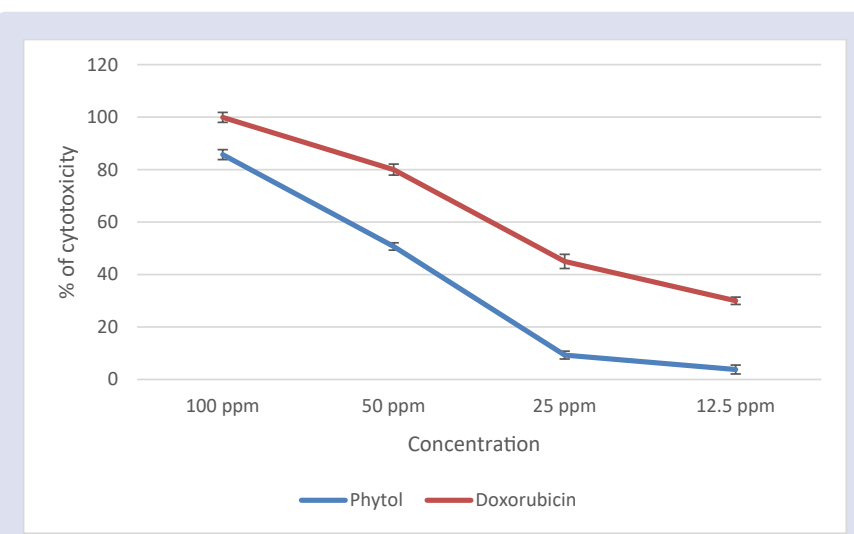

Figure 4: Percentage of cytotoxic effect of phytol on breast human tumor cell line MCF-7 at different concentration (100-12.5 ppm) compared with the reference drug Doxorubicin. Each result is a mean of 3 replicate samples.

results, it can be concluded, that Jacquemontia pentantha has potent cytotoxic effect on breast and colon tumor cell line.

\section{DISCUSSION}

The aerial parts of the plant were extracted with chloroform- methanol (3:1) till exhaustion. The extract was subjected to silica gel column chromatography. The fractions obtained were examined using TLC and the similar fractions were collected to give five major fractions, from which 8 compounds were isolated from this plant. By means of spectroscopic analysis, they were identified as, Palmitic acid (1), Phytol (2), Stigmast-4-en-3-one (3), a-amyrin (4), $\beta$-amyrin (5), $1,6,10,14,18,22$-Tetracosahexaen-3-ol,2,6,10,15,19,23- hexamethyl (all-E) (6), $\alpha$-amyrin acetate (7), $\beta$-amyrin acetate (8). The isolated terpenes and sterols were identified on the basis of UV, Mass spectrum, ${ }^{1} \mathrm{HNMR}$ and ${ }^{13} \mathrm{CNMR}$ data and compared with literature.

Cell-based assays are often used for investigation proliferated profile of studied plant extract, which is a reliable indicator of cellular energy capacity of the cell through enzymatic reducing effect of 3-[4, 5-dimethylthiazole-2-yl]-2,5-diphenyltetrazolium bromide (MTT) to MTT-formazan governed by Mitochondria enzyme succinate dehydrogenase. So, in the present study we explore the proliferative effect of crude extract of Jacquemontia pentantha on breast and colon human tumor cell line namely MCF-7, HCT-116.

Microtubules are dynamic protein filaments represented major structural components of the cytoskeleton assembled from polymers of $\alpha$ - and $\beta$-tubulin subunits, which play a key role for cell signaling, cell 
migration, and cell proliferation. The critical role of microtubules in cell division and other cellular functions makes them an attractive target for cancer chemotherapy. Microtubule-targeting agents such as the taxanes and the vinca alkaloids represent a successful class of anticancer drugs affect their dynamics by inhibiting cell proliferation..$^{29}$ Jacquemontia pentantha extract has antiproliferative effect on two tumor cell line namely (MCF-7 and HCT-116) is through affecting microtubulepolymer mass resulting in cell death. As cancer is a life-threating disease, phytol was found to exhibit a potent antitumor on MCF-7 breast cell line. Phytol can be used as a precursor for the manufacture of synthetic forms of vitamin $\mathrm{E},{ }^{30}$ and vitamin $\mathrm{K} .{ }^{31}$

\section{CONCLUSION}

These eight compounds (sterols and terpenes) were isolated here for the first time from the crude extract of Jacquemontia pentantha. The results revealed that the crude extract showed potent cytotoxic activity on both breast and colon human cell lines. Phytol is reported here as a major compound and was found it has a potential role in the cytotoxic effect of Jacquemontia pentantha on breast cell line, along with other compounds. Further investigation needs to be done to elucidate the compounds mode of action responsible for the antiproliferative effect for these compounds could be promising cytotoxic agents in treatment of human cancer.

\section{REFERENCES}

1. Rajia S, Mahbubur RAHM. Convolvulaceae: A taxonomically and medicinally important morning glory family. International Journal of Botany Studies. 2016;1(3):47-52.

2. Mahmoud IN, El-Sayed AA, Dina ME, Mary HG, Amany AS, Ezzeldin AE, et al. A new acylated flavonol triglycoside and Bioactivities of Jacquemontia pentantha (Jacq.). Research Journal of Pharmaceutical, Biological and Chemical Sciences. 2015;6(6):677-86.

3. Leistner E, Steiner U. Fungal origin of ergoline alkaloids present in dicotyledonous plants Convolvulaceae, T, Weber D (eds.) Physiology and genetics. $1^{\text {st }}$ ed, Springer-Verlag Berlin Heidelberg, Berlin, Germany, p.197208;2009.

4. Eich E. Solanaceae and Convolvulaceae: Secondary metabolites: biosynthesis, chemotaxonomy, biological and economic significance. $1^{\text {st }}$ ed, Springer- Verlag Berlin Heidelberg, Berlin, Germany;2008.

5. Mahmood N, Moore PS, Tommasi ND, Simone FD, Colman S, Hay AJ, et al. Inhibition of HIV infection by caffeoylquinic acid derivatives. Antiviral Chemistry and Chemotherapy. 1993;4:235-40.

6. Panaccione DG. Origins and significance of ergot alkaloid diversity in fungi. FEMS Microbiology Letters. 2005;251:9-17.

7. Ferreira AA, Amaral FA, Duarte IDG, Oliveira PM, Alves RB, Silveira $D$ et al. Antinociceptive effect from Ipomoea cairica extract. Journal of Ethnopharmacology. 2006;105:148-53.

8. Malalavidhane S, Wickramasinghe SM, Jansz ER. An aqueous extract of the green leafy vegetable Ipomoea aquatica is as effective as the oral hypoglycaemic drug to lbutamide in reducing the blood sugar levels of Wistar rats. Phytotherapy Research. 2001;15:635-37.

9. Cho MK, Jang YP, Kim YC, Kim SG. Arctigenin, a phenylpropanoid dibenzylbutyrolactone lignan, inhibits MAP kinases and AP-1 activation via potent MKK inhibition: the role in TNF-alpha inhibition, International Immunopharmacology. 2004;10(11):1419-29.

10. Mahmoud IN, Elsayed AA, Dina ME, Amany AS, Ezzeldin AE. Isoquercitrin, the major constituent from Jacquemontia pentantha (Jacq.): hepatoprotective evaluation of the extracts. Research Journal of Pharmaceutical, Biological and Chemical Sciences. 2016;7(4):1616-21.
11. Thabrew M, Hughes RD, Mcfarlane IG. Screening of hepatoprotective plant components using a HepG2 cell cytotoxicity assay. Journal of Pharmacy and Pharmacology. 1997;49(11):1132-35.

12. Moustafa SM, Menshawi BM, Wassel GM, Mahmoud K, Mounier MM Screening of some plants in Egypt for their cytotoxicity against four human cancer cell lines. International Journal of Chem Tech Research. 2014;6(3):107484.

13. Mosmann T. Rapid colorimetric assay for cellular growth and survival: application to proliferation and cytotoxicity assays. Journal of Immunological Methods. 1983;65(1):55-63.

14. Liliom K, Lehotzky A, Molnar A, Ovadi J. Characterization of tubulin-alkaloid interactions by enzyme-linked immunosorbent assay. Analytical Biochemistry. 1995;228(1):18-26.

15. Giang PM, Dang THN, Nguyen XH, Phan TS. Further chemical constituennts of Scoparia dulcis L. (Scrophulariaceae) originating in Vietnam. Journal of Chemistry. 2009;47(5):640-46.

16. Bulama JS, Dangoggo SM, Halilu ME, Tsafe AI, Hassan SW. Isolation and characterization of palmitic acid from ethyl acetate extract of root bark of Terminalia glaucescens. Chemistry and Materials Research. 2014;6(12):140-3.

17. Gunawan A, Arlene C, Anamy P. Structure elucidation of two new phytol derivatives, a new phenolic compound and other metabolites of Averrhoa bilimbi. Presented at the Research Congress, De La Salle University Manila. 2013;p:7-9.

18. Arigoni D, Eisenreich W, Latzel C, Sagner S, Radykewicz T, Zenk MHBA Dimethylallyl pyrophosphate is not the committed precursor of isopentenyl pyrophosphate during terpenoid biosynthesis from 1-deoxyxylulose in higher plants. Proceedings of the National Academy of Sciences. 1999;96:1309-14.

19. Kui S, Min G, Jing Z, Shiming D. Study on chemical composition of Nauclea officinalis leaves. International Journal of Chemistry. 2009;1(2):77-82.

20. Ufuk K, GulactT, Seher B, Gulten O, Ayhan U. Terpenoids and steroids from the roots of Salvia Blepharochlaena. Turkish Journal of Chemistry. 2005;29:177-86.

21. Consolacion YR, Oscar BT, Jessa MPG, Hannah PBCK, Chien-Chang S Triterpenes and Acylglycerols from Canariumovatum. Journal of Applied Pharmaceutical Science. 2015;5(4):94-100.

22. Cordeiro SZ, Simas NK, Arruda RCO, Sato A. Composition of epicuticular wax layer of two species of Mandevilla (Apocynoideae, Apocynaceae) from Rio de Janeiro, Brazil. Biochemical Systematics and Ecolog. 2011;39:198-202.

23. Wang $F$, Li Z, Cui $H$, Hua $H$, Jing $Y$, Liang $M$. Two new triterpenoids from the resin of Boswellia carterii. Journal of Asian Natunal Products Research. $2011 ; 13(3): 193-7$.

24. Slavyana I, Vesselin T, Norihiko Y, Marta CY, Douglas B, Georgi AsG. Surface properties of squalene/meibum films and NMR confirmation of squalene in tears. International Journal of Molecular Sciences. 2015;16:21813-31.

25. Alejandro FB, Herrador MM, Arteaga P, Ignacio RG, Manuel GM. Resorcinol derivatives and flavonoids of Ononis natrix Subspecies ramosissima. Journal of Natural Products. 1997;60(2):65-8.

26. Veerabahu RM, Jenecius AA, Uthayakumari F. GC-MS determination of bioactive components of Sauropus bacciformis BLUME (Euphorbiaceae). Journal of Current Chemical and Pharmaceutical Sciences. 2012;2(4):347-58.

27. Sisay F, Abeba B. Triterpene compounds from the latex of Ficus suri. Bulletin of the Chemical Society of Ethiopia. 2005;19(2):307-10.

28. Ali N. Brine shrimp cytotoxicity of crude methanol extract and antispasmodic activity of a-amyrin acetate from Tylophora hirsute Wall. BMC Complementary and Alternative Medicine. 2013;13:135-41.

29. Sakchaisri K, Kim SO, Hwang J, Soung NK, Lee KH, Choi TW, et al. Anticancer activity of a novel small molecule tubulin inhibitor STK899704. PloS One. 2017;12(3):e0173311.

30. Thomas N. Synthesis of vitamin e, vitamins and hormones, $1^{\text {st }}$ ed. Litwack Gerald, 76, Academic press, California, USA, 2007;pp.155-202.

31. Alison MD, Richard JP, Mark EH, Andrew DA. The synthesis of naturally occurring vitamin $\mathrm{k}$ and vitamin $\mathrm{k}$ analogues. Current Organic Chemistry. 2003;7(16):1625-34. 


\section{GRAPHICAL ABSTRACT}

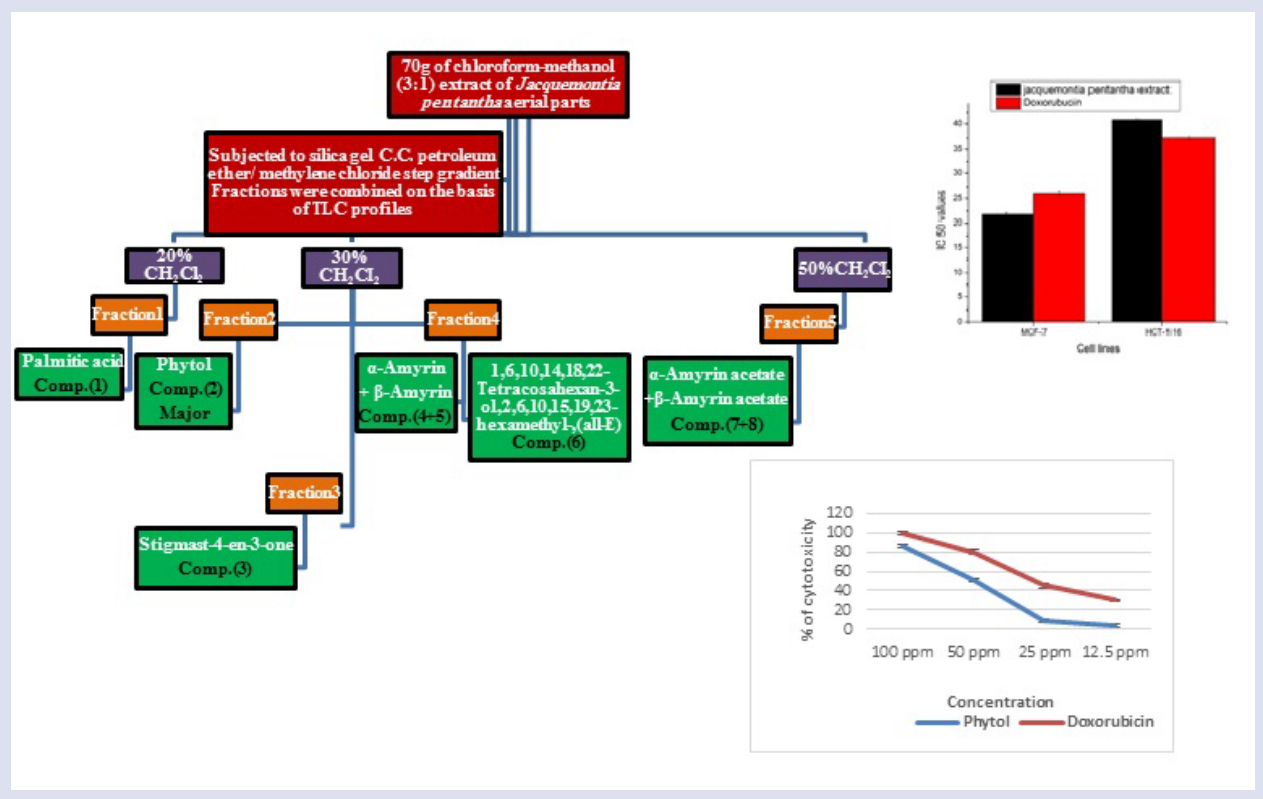

\section{SUMMARY}

The aim of this study is to isolate and identify sterols and terpenes from the chloroform/methanol extract (3:1) of aerial parts of Jacquemontia pentantha (Jacq.) and evaluation of cytotoxic activity of crude extract and phytol for the first time from this plant. Different chromatographic techniques were used resulting in isolation of eight compounds for the first time from this plant, were identified as: Palmitic acid, Phytol (major), Stigmast-4-en-3-one, mixture of $\alpha$-amyrin and $\beta$-amyrin, 1,6,10,14,18,22-Tetracosahexaen-3-ol,2,6,10,15,19,23-hexamethyl (all-E) and mixture of $\alpha$-amyrin acetate and $\beta$-amyrin acetate .Their structures were elucidated by spectroscopic methods including ${ }^{1} \mathrm{HNMR},{ }^{13} \mathrm{CNMR}, \mathrm{El} / \mathrm{MS}$ spectrometry and by comparing their data with those reported in the literature. Cytotoxicity was evaluated using MTT assay. Mode of action of extract was predicted by using Enzyme-linked Immunosorbent Assay Kit for Tubulin beta (TUBb). The extract showed potent cytotoxic activity on MCF-7 breast carcinoma cell line as well as HCT-116 colon carcinoma cell line at different concentrations (100-6.25 ug/ml) with $\mathrm{IC}_{50}(21.8 \pm 0.9)$ and $(40.9 \pm 1.3)$ respectively. It showed more potency than drug reference doxorubicin on breast tumor cell line. Phytol showed potent cytotoxic activity on MCF-7 cell line at different concentrations $(100-12.5 \mathrm{ug} / \mathrm{ml}) \mathrm{with} I \mathrm{C}_{50}(60 \pm 2.4)$, while it had no cytotoxic effect on HCT-116 cell line. Extract showed significant TUBb polymerization inhibition activity. It has antiproliferative effect on tumor cell line namely (MCF-7, HCT-116), through affecting microtubule-polymer mass resulting in cell death. Cytotoxic activity due to presence of phytochemicals as sterols and terpenes.

\section{ABOUT AUTHORS}

Dina Eskander is a Researcher at the Department of Chemistry of Natural Compounds, National Research Centre, Egypt. She obtained Master \& PhD from Cairo University, Faculty of Pharmacy.

Mary Grace is Professor at Plants for Human Health Institute Department, North Carolina State University, USA.

Mahmoud Nassar is Professor at Chemistry of Natural Compounds Department, National Research Centre.

Ezzel Din El Khrisy is Professor at Chemistry of Natural Compounds Department, National Research Centre.

Marian Nabil is Researcher at Chemistry of Natural Compounds Department, National Research Centre.

Marwa Mounier is Researcher atPharmacognosy Department, Drug Bioassay Cell Culture Laboratory, National Research Centre.

Cite this article: Eskander DM, El-Khrisy EA, Grace MH, Nabil M, Nassar MI, Mounier MM. Investigation of Secondary Metabolites and Cytotoxicity of Jacquemontia pentantha (Jacq.). Pharmacog J. 2019;11(4):718-23. 